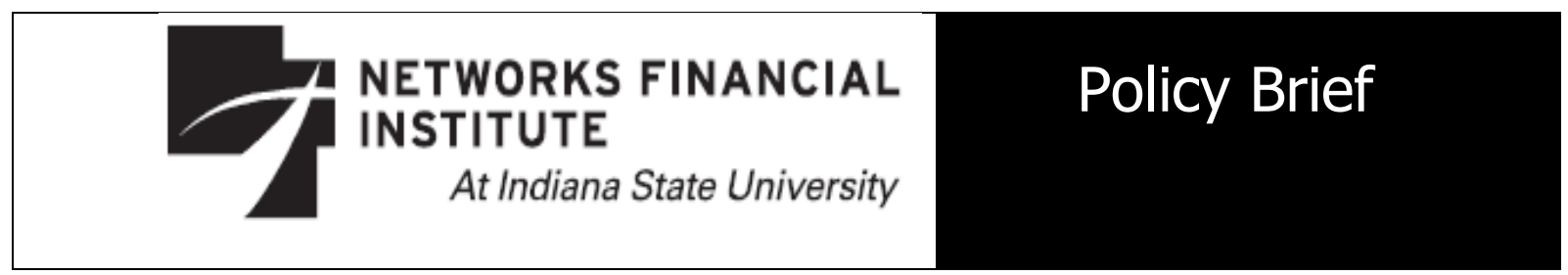

2010-PB-04

August 2010

\title{
The Lure of Leveraging: Wall Street, Congress and the Invisible Government
}

\section{James A. Leach}

Abstract: The author reviews the legislative framework of financial regulation, assesses public and private sector accountability for the economic trauma loosed in 2008, and appraises the legislative aftermath. His thesis is that the economy and the financial security of the country were unnecessarily jeopardized by the unchecked greed of a few; that at critical moments politics and ideology dominated regulatory decision-making; that the regulators, the invisible government, allowed excess leveraging out of excess confidence in risk-based mathematical modeling; that a conflicted Congress emboldened risk-taking at Fannie Me and Freddie Mac; and that problems in commercial bank regulation related less to what Congress did than what it didn't do. As both a participant and observer in the legislative process, he has designed this review in part as a chronicle of Congressional interactions between the parties and with the Executive branch and in part as a take on regulation itself.

About the Author: James A. Leach is Chairman of the National Endowment for the Humanities. Prior to being nominated by President Obama for the post, Leach was a Professor at the Woodrow Wilson School at Princeton University and Interim Director of the Institute of Politics and Lecturer at the Harvard Kennedy School. Leach's brief stint in academia was preceded by 30 years of service as a representative in Congress where he chaired the Banking and Financial Services Committee, the Subcommittee on Asian and Pacific Affairs, and the Congressional-Executive Commission on China. Leach attended Princeton, the School of Advanced International Studies of Johns Hopkins, and the London School of Economics. He holds ten honorary degrees, has received decorations from two foreign governments, and is the recipient of the Wayne Morse Integrity in Politics Award, the Adlai Stevenson Award from the United Nations Association, the Edger Wayburn Award from the Sierra Club, the Norman Borlaug Public Service Award, and a Woodrow Wilson Award from both Princeton and Johns Hopkins. Leach served on the board of several public companies and a series of non-profit organizations, including the Century Foundation, the Carnegie Endowment for International Peace, the Social Sciences Research Council, Pro Publica and Common Cause which he chaired. He is a member of the Council on Foreign Relations and formerly served as a trustee of Princeton University.

The views expressed are those of the individual author and do not necessarily reflect official positions of Networks Financial Institute, the National Endowment for the Humanities or the United States government. The perspective taken is based in part on two addresses the author delivered, one to a conference on "Regional and National Financial Crises: Roots, Results and Responses," held at the Policy Research Institute at the Woodrow Wilson School at Princeton University on November 7, 2008, and one prepared for the "Symposium on Shaping Global Financial Reform," sponsored by the Bretton Woods Committee and the Boston University School of Law, held in Washington, D.C., on April 22, 2009. Please address questions regarding content to James A. Leach at jleach@neh.gov. Any errors or omissions are the responsibility of the author. NFI policy briefs and other publications are available on NFI's website (www.networksfinancialinstitute.org). Click "Thought Leadership" and then "Publications/Papers." 


\section{The Lure of Leveraging: Wall Street, Congress and the Invisible Government}

\section{James A. Leach}

It is my intent to review the legislative framework of financial regulation, assess public and private sector accountability for the economic trauma loosed in 2008, and appraise the legislative aftermath. My thesis is that the economy and the financial security of the country were unnecessarily jeopardized by the unchecked greed of a few; that, at critical moments, politics and ideology dominated regulatory decision making; that the regulators, the invisible government, allowed excess leveraging out of excess confidence in risk-based mathematical modeling; that a conflicted Congress emboldened risk taking at Fannie Mae and Freddie Mac; and that problems in commercial bank regulation related less to what Congress did than what it didn't do. As both a participant and observer in the legislative process, I have designed this review in part as a chronicle of Congressional interactions between the parties and with the Executive branch, and in part as a take on regulation itself. Accordingly, I apologize for presumptuous overuse of the "I" word and the presentation of an unavoidable personal perspective.

\section{The Pre-2010 Framework of Financial Regulation}

Let me begin with a counterintuitive observation. The institutional framework of our financial regulatory system - the mix of federal and state regulatory bodies - has changed little in the past half century. Markets have changed dramatically but the regulatory governance structure has not. The Gramm-Leach-Bliley Act of 1999 (GLBA), for instance, changed part of the competitive but little of the regulatory framework of the Glass Steagall Act, which dates to the early years of the Great Depression. Indeed, it added to, rather than subtracted from, federal oversight authority over fast-changing markets.

By background, Glass Steagall and the Bank Holding Company Act had defined three cocoons of financial activity - commercial banking, investment banking, and insurance. While investment banks were allowed under these two acts to combine and compete against insurance companies, commercial banks were not allowed to engage in investment banking or insurance underwriting. What GLBA authorized was increased competition within the financial community with the maintenance of historically tested functional regulation. Banking activities in newly authorized multipurpose financial companies would be regulated by state and federal banking authorities, securities functions by state and federal securities commissions, and insurance by state insurance departments.

The GLBA restructured the competitive framework to recognize technological changes in the economy and reflect market place changes that had taken place, including changes in state law and federal rule making.

During the twentieth century, the most profound competitive changes in the banking arena related to the manner Americans chose to save and invest. At the beginning of the century, 
three fourths of American savings were managed by commercial banks. By the century's end, only one quarter of the saved dollar entered the banking system, jeopardizing in many parts of the country its capacity to tap community savings to reinvest in the community itself.

Driving consensus in the 1990s on the need for a statutory review of competitive legal constraints in the financial industry was a graduated series of preemptive determinations of the Treasury Department's Office of the Comptroller of the Currency (OCC) allowing national banks to engage in aspects of investment banking. In a cumulative manner, these OCC determinations coupled with Federal Reserve approvals of various activities "incidental to banking" had significantly begun to breach Glass Steagall's competitive walls. These unilateral authorities and the manner in which they were structured were seen as inducements to conflicts of interest within banks, particularly national banks. They were also competitively disadvantageous to other parts of the financial industry: securities and insurance firms and community banks. Hence Congress chose to adopt a new approach designed to advance competitive equality for each part of the financial industry and provide an umbrella of equalitarian regulation.

Contrary to popular assumption, Glass Steagall was modified rather than repealed. Much remained intact. Restrictions, for instance, on investment banks accepting deposits and commercial banks investing in commercial activities were maintained. And what was then considered a loophole in law, a provision that allowed commercial firms to own unitary thrifts, was closed with passage of GLBA.

The most controversial provision under consideration during the GLBA debate was whether banks or bank holding companies could merge with commercial companies - i.e., whether a Citicorp could merge with a Wal-Mart or Microsoft or Enron. If this feature of federal law had been removed, enormous new incentives would have been given to the biggest American banks, or the industrial firms that would inevitably come to control them, to leverage depositor dollars to buy corporate assets rather than lend to American families and jobmaking entrepreneurs. The mission of banking would have been transformed from stimulating innovation and entrepreneurship to precipitating asset conglomeration, and the American ideal would have shifted from spreading opportunity to concentrating wealth in fewer hands.

In the end, as chairman of the House Banking Committee, I was barely able to keep this radical breach of the wall between banking and commerce from occurring. But it was a close call. Congressional leadership of both parties in both bodies largely supported this change, as did the other two chairmen of the relevant committees of jurisdiction and several of the most powerful bank lobbying groups. At one point, the Treasury was in full and the Federal Reserve (Fed) in partial agreement, proposing what it described as a step-by-step "basket" approach, but fortunately each, with the passage of time, reconsidered, in part perhaps 
because I had indicated that I would do my utmost to pull the plug on any bill that contained such a provision. ${ }^{1}$

If the prohibition on the repeal of mixing commerce and banking - the heart of Glass Steagall and the Bank Holding Company Act - had been repealed, the recent financial contagion could have tripwired even more adversely from Wall Street to the industrial heartland. What did not happen in Glass Steagall reform was more important than what did.

Like cicadas, insider advocates of merging commerce and banking resurface periodically in Washington. The public has never paid much attention to the issue and its consequences, but in a political system where money power games are not unknown, it is the kind of mischievous initiative that can suddenly take legislative hold outside the public spotlight.

The regulatory edifice established by GLBA was intended to bring greater order to the financial market place where: 1) despite a prohibition in banking law against a bank buying an insurance company, the Clinton Administration had allowed a large insurance company, Travelers, to do the reverse in a merger in which it became the technical purchaser of our largest commercial bank, Citicorp; and 2) the OCC had through aggressive rule making began in the 1990s to erode barriers between bank and non-bank financial activities under a regulator-empowering Supreme Court ruling, the Chevron decision, which, in effect, held that the courts should give deference to federal regulators as long as their judgments were not capriciously derived. The OCC also allowed newly authorized insurance and securities activities to be conducted within the bank itself, i.e., without the necessity for a bank to establish separately capitalized and regulated subsidiaries.

To reduce internal banking conflicts of interest, GLBA demarcated activities traditionally subject to deposit insurance from activities of a different nature and required non-traditional banking activities to be separately funded and regulated. The reform intent of GLBA was to require banks to have adequate capital, transparently reviewable in separable categories to match whatever new risks developed with new activities.

In addition, GLBA established the most extensive privacy regulation in the history of Congress and required that every financial enterprise have a primary regulator to insure, among other things, that no product slipped through a regulatory crack, a provision that had become compelling because an increasing number of hybrid products had come to market that were part insurance, part banking and part securities in nature.

\footnotetext{
${ }^{1}$ In an effort to reduce the intensity of banking industry lobbying for this change in the late 1990s, I sent letters to the CEOs and general counsels of the largest banks with an analysis of the relative value of commercial firms to banks on public exchanges. Only one bank (Citicorp) at the time was in the top 20 (it was $20^{\text {th }}$ ) in market value of companies on the New York Stock Exchange. At the risk of presumption, I suggested that it was naïve for bankers to assume that a law suddenly allowing the merging of commerce and banking would put bankers in the mergers and acquisitions driver's seat. Wouldn't, I asked, companies like Amoco, Microsoft, Wal-Mart, and G.E. not quickly move to control major financial institutions? Months later, at a luncheon in which I addressed a Federal Reserve advisory committee composed of major bank CEOs, a banker wryly noted that my letter had been widely discussed. The consensus, he noted, was that while he and his colleagues disagreed with my position, they understood this might be an inopportune time to proceed with so profound a breach of Glass Steagall. Nevertheless, the lobbying on Capitol Hill never abated.
} 
In this context, GLBA called for the Federal Reserve to be the umbrella regulator of financial holding companies. As a consolidated supervisor, the Fed was given responsibility for imposing holding company capital requirements and insuring that all aspects of any multipurpose financial holding company were subject to appropriate regulatory oversight. Analogously, the GLBA authorized the U.S. Securities and Exchange Commission (SEC) to be the consolidated regulator of investment bank holding companies.

To reduce industry capacity to seek the least level of regulation by arbitraging regulatory agencies, the act called for greater regulatory cooperation and commonality of approaches. Of particular importance, it mandated in key areas joint Federal Reserve and Treasury Department decision-making. Government-to-industry regulatory order was not only expected to be maintained, but enhanced and streamlined.

One of the most important things that the legislation did in relation to the financial meltdown of the past few years is help to insulate smaller banks from the liquidity traumas that inevitably follow erosions in public confidence. By allowing smaller, but not larger, institutions to tap Federal Home Loan Banks for liquidity through the option of selling or collateralizing agricultural and small business loans, an extra liquidity backstop was given community banks.

In sum, financial markets changed dramatically in the post World War II era but except for the addition of more coherence under GLBA, the superstructure of regulation changed little.

\section{The Invisible Government}

There are many ways to organize regulation. The current regulatory regime can and should be improved and I will touch later on various approaches, most of which were pressed to little avail during my career in Congress. Nonetheless, if one assumes that the framework of regulation defined by GLBA is rooted in history and steeped in precedent, why have we just witnessed the greatest regulatory failure in the history of the planet?

In banking regulation, the one judgment that cannot be ducked over the last decade might be described as the nurture versus nature question. Is it the organization of decision making that failed or is it the invisible government - the panoply of federal regulatory bodies - that erred in reducing reliance on capital ratios for supervision of large financial institutions and giving deference instead to risk-based, mathematical modeling that accommodated ever riskier offbalance sheet and derivatives investment strategies?

Assessment of whether regulatory failure is principally judgmental or organizational matters, for it has everything to do with applying lessons to failed circumstances. Are the lessons to be learned first and foremost about arrangement of regulatory boxes or about imprudent regulatory judgment in the public sector and improvident risk taking in the private? 
For those who hold that modification of Glass Steagall is part of the problem at hand, several points deserve review. The year before Glass Steagall was modified in 1999, Travelers had used a legal loophole to merge with Citicorp, and two years before the current financial collapse, the holding company, Citigroup, had divested itself of Travelers. There is no evidence: a) that the securities industry got into trouble doing too much commercial banking, or marketing and underwriting of insurance; b) that the insurance industry erred by doing too much investment or commercial banking; or c) that commercial banks and insurance companies got into fundamental difficulty engaging in activities they couldn't have engaged in before Glass Steagall was modified. Commercial banks and insurance companies, after all, have always been able to deal in mortgage products and, since their invention, in mortgage and other finance-related derivatives.

Likewise, GLBA did not change the types of financial products that could be sold to investors by government sponsored enterprises (GSEs) in housing or Wall Street securities firms which were able under Glass Steagall to invest in and trade the kinds of assets that wreaked such recent financial havoc. As for individual entities from Fannie Mae and Freddie Mac to American International Group (AIG) to Lehman Brothers and Bear Stearns, all could have made the same problematic investment decisions under the pre-GLBA structure. None were subject to commercial bank regulation.

As for commercial banks doing investment banking, the most talked about legislative issue in the 1990s was whether it was appropriate to allow them to compete with securities firms in merger and acquisition activities. Such activities - the golden egg of investment banking have not caused commercial bank solvency problems. They proved to be profitable, increased competitive choices for American industry, and allowed consumers more decentralized financial options.

Not only is evidence lacking that changes in Glass Steagall precipitated this crisis, it is because of Glass Steagall reform that a far greater cratering of investment banking did not occur. For instance, JPMorgan Chase was able to assume Bear Stearns and Bank of America was able to take over Merrill Lynch. And, after others assumed most of the lossembedded investments of Lehman Brothers, Barclays embraced its structural and operating assets. The elimination of these investment banks, which would have been quite conceivable if Glass Steagall had not been reformed, could have caused a far greater confidence crisis than otherwise proved to be the case. Now each is subject to bank holding company capital requirements, activity restrictions, and general oversight, as are Goldman Sachs and Morgan Stanley. 


\section{What Then Happened?}

What is impressive as post-mortem reviews take place is not what is newly figured out, but how many of the problems that precipitated the current financial crisis were known in advance. With few exceptions, it was widely understood in financial circles that:

a) ethical lapses can quickly erode public confidence in finance more than in any field of commerce because finance depends so completely on trust;

b) at a macro level, for a number of years we Americans have been spending approximately 5 percent more than the country produces, mortgaging our future with twin fiscal and trade deficits;

c) at a micro level, housing prices over much of the country increased faster than household income or inflation, spurred by a monetary policy designed to keep interest rates low, a sudden adoption by an historically conservative mortgage industry of lax lending standards, and a spike in fraud among mortgage brokers;

d) at a political level, an American administration had lost worldwide confidence related to a war financed with tax cuts against a country that did not attack us;

e) Congress had adopted an egregiously inadequate regulatory framework for the two housing related GSEs, Fannie Mae and Freddie Mac.

f) the ability of Wall Street firms to market mortgage portfolios rated by agencies with inherent conflicts got ahead of their willingness to do disciplined due-diligence reviews of products sold, with gross inattention to the quality of appraisals and income verification of borrowers;

g) like any manufactured item produced without adequate quality controls, mortgage portfolios could plummet in resale value if defective standards existed;

h) trade in sliced and diced mortgage portfolios and an assortment of derivatives products grew at a rate that was inherently destabilizing, given the lack of widespread product standardization and absence of generalized clearing capacities;

i) U.S. money center banks were allowed to adopt leverage ratios far higher than community banks and use, sometimes imprudently, non-transparent off-balance sheet accounting techniques;

j) at the turn of the new millennium, international financial regulators in Basel, with the approval of the U.S. Federal Reserve, authorized unprecedented leveraging for multinational banks, allowing them to move away from reliance on traditional capital ratios to untested risk-based modeling approaches developed at individual institution discretion; 
k) in the middle of the 2004 presidential campaign, the SEC, citing Basel standards, gave a green light for the largest securities firms to increase their leverage and then failed to provide adequate oversight of their investment and accounting practices;

1) a division of the Treasury Department, the Office of Thrift Supervision (OTS), was given responsibility to share with the New York Insurance Department oversight responsibility for the London branch of AIG and neither regulatory body understood the nature of the risk implicit in credit default swaps;

m) in a little noted regulatory initiative in another election year (2000), the Treasury Department's OCC bypassed traditional administrative procedures and without public or Congressional input gave national banks the power to skirt law and invest in equity securities as part of their derivative strategies, ${ }^{2}$ thus providing an unlegislated green light to national banks to do proprietary trading - i.e., speculating - implicitly with insured deposits; and

n) despite legislative authorization for the creation and oversight of swaps clearing facilities in the Commodity Futures Modernization Act (CFMA) of 2000, regulators did not begin to press the establishment of such clearing facilities until the last months of the Bush administration when it was too late to stem the financial meltdown.

In sum, from a regulatory perspective, the debasement of bank standards abroad sanctioned in the Basel process was matched by standards reduction at home. Leveraging excesses were exacerbated by the irresponsible marketing and insuring of faulty mortgage portfolios and the failure to recognize the macroeconomic liabilities associated with a mushrooming derivatives market that had no universal clearing mechanisms.

There was also a largely unnoted failure of law enforcement. In the wake of 9/11, much public attention was properly given to problems of coordination between the federal agencies responsible for reviewing international threats (principally the Central Intelligence Agency) and the federal agencies responsible for domestic threats (principally the Federal Bureau of Investigation) and local law enforcement. An analogous problem arose in finance. The parts of the national government most responsible for threats to the financial system (principally the Treasury Department and the Federal Reserve) appeared not to give priority attention and/or lacked the capacity to press coordination with the Justice Department and local law enforcement on the implications of unprecedented fraud, particularly but not exclusively in inner cities, that had developed in the mortgage brokering industry.

The mortgage development process had for generations been assumed to be principally one where a prospective home owner would approach a commercial bank or savings and loan (S\&L) and in a careful, often cumbersome, process be required to document income, with the financial institution doing an independent appraisal of the property. But as a consequence of

\footnotetext{
${ }^{2}$ In my last year as the term-limited chairman of the House Banking Committee, I objected strenuously both to the judgment and rulemaking process that regulators followed and to no avail provided Treasury's Inspector General with a detailed complaint.
} 
the development of computer modeling and swift capacities to sell mortgages up the financial chain to secondary and tertiary markets, a mortgage brokering industry that skipped federally insured intermediaries expanded significantly. Instead of working almost exclusively with comprehensively regulated institutions that had a vested interest in mortgage quality due in no small part to the extensive maintenance of mortgages in internal portfolios, Wall Street and the housing GSEs found themselves increasingly dealing with lightly regulated brokers who lacked skin in the game as they quickly sold their mortgage contracts into a secondary market.

When brokers developed the immediate capacity to unload upstream their mortgage contracts, they effectively transferred contract liabilities to others. The same situation applied at the secondary level for products bundled and resold to tertiary markets. If these products were subsequently found to be overvalued either because of wrenches in the economy or because of fraudulent origination numbers, the losses were assumed to be transferred to secondary or tertiary holders of mortgage portfolios.

The principal long-term damage to Wall Street is the deterioration in the reputation of individual firms, with those who maintained large mortgage portfolios also suffering substantial financial losses. Some were such good salesmen that they fooled themselves. The losses to Fannie Mae and Freddie Mac were substantially larger than any Wall Street institution because they were bigger market players, because they maintained a greater percentage of the mortgages they bought, and because they often guaranteed payment streams on mortgage portfolios they sold.

The same inadequacy of coordination between regulators and law enforcement agencies applied to identity theft and Internet gambling offenses. The lack of coordination in these areas where laws were also routinely breached was at most a tangential aspect of the financial trauma of 2008. But both of these unlawful elements of finance, especially Internet gambling, could grow in significance for many American families and the economy itself in coming years.

\section{Congressional Accountability}

Aside from the macro issues of war and the deficits, it is laws at the intersection of finance and housing where Congressional accountability for the financial meltdown is most stark. While financial institutions like Fannie Mae, Freddie Mac, and AIG initially recorded sizable profits in purchasing, marketing and insuring packages of housing products, their losses came in the end to be so large that taxpayers have been forced to pick up hundreds of billions of dollars in liabilities.

If one were to define the current economic trauma as a single industry debacle, it is a close call whether to describe it as principally a result of excesses in the housing or financial industry. At the heart of Congressional responsibility is the captive regulator model 
established by statute in 1994 for Fannie Mae and Freddie Mac. The legislation that set up the regulatory scheme for these housing GSEs was an egregious example of Congressional capitulation to interest group pressure. More constraints were put on the regulator than the regulated.

But the marketing of sliced and diced mortgage portfolios was complicated by the growth in markets of new kinds of derivative products. Concerned for the stability of these markets, I issued in 1993 as the ranking member of the then-named Committee on Banking, Finance and Urban Affairs a 902-page report on regulating derivatives. ${ }^{3}$

What came to be called the Leach Report, I later learned, was widely read by regulators in the principal financial capitals around the world because government agencies everywhere were apprehensive of putting out comprehensive approaches that might offend affected parties. Based on interviews and written exchanges with academia, industry, and the regulatory community, the 30 recommendations for derivatives regulation which it contained represented at the time the most wide-ranging series of recommendations any governmental body had publicly set forth on the subject.

Relevant today in the recommendations made seventeen years ago were calls for strong capital standards for financial institutions regardless of the development of other risk-based approaches, the application of capital requirements for off-balance sheet instruments, the establishment of comparable standards and market rules for non-banks as well as banks, the international harmonization of standards, the standardization of documentation, and the development of protections against systemic risk.

Following up on the report that winter, I introduced a bill to establish a Derivatives Commission to enhance the federal framework for regulation of derivative activities. In introducing the bill on the House floor, I noted in my opening statement that:

$[\mathrm{M}] \mathrm{y}$ operating assumption is that derivatives are the new wild card in international finance. There is an American adage: "I wouldn't do that for all the money in the world." Interestingly, the multitrillion dollar derivatives activities of the ten largest American commercial banks alone amount to double the annual [gross national product] of the United States which, in turn, is more money than all the money in the world. If this doesn't define a pyramidal house of cards - particularly in the event of a market shock sparked abroad by warmongers or at home by private sector speculators or public pandering protectionists - what does?

\footnotetext{
${ }^{3}$ The report was printed as an appendix to a hearing before the Committee on Banking, Finance, and Urban Affairs. See Safety and Soundness Issues Related to Bank Derivative Activities: Hearing Before the Committee on Banking, Finance, and Urban Affairs, House of Representatives, One Hundred Third Congress, first session. Washington : U.S. G.P.O., 1994.
} 
Everett Dirksen once commented that a billion here and there pretty soon added up to real money. With regard to derivatives, it would appear that a trillion here and there may add up to a real problem.

As the federal deficit bears proof, Congress has yet to understand how to manage figures followed by [nine] digits. With derivatives it is asked to understand quantumly larger figures - numbers followed by [twelve] digits.

Derivatives pose a conundrum in that the problems they present may be too sophisticated for a Congress of generalists to deal with in any detail. However, this does not mean that legislators do not have the responsibility to set forth a general framework of concerns with the understanding that the executive branch and Federal Reserve must be held accountable for responsible oversight of the financial markets."

Half a decade after these observations, Brooksley Born, a relatively new head of the U.S. Commodities Future Trading Commission (CFTC), broke with her administration and her predecessors at the CFTC to indicate in a highly publicized "concept" release that her agency was contemplating taking the lead in regulating swaps based contracts with an implicit unilateral assertion of jurisdiction over these markets by her agency. The Federal Reserve, Treasury and U.S. Securities and Exchange Commission (SEC) bitterly objected on legal and competence grounds.

In a contentious 1998 hearing, they pointed out that if the CFTC attempted to take such a step without statutory change, the legal certainty of trillions of dollars of existent swaps contracts could be challenged, potentially causing an international financial tremor, with the trading of swaps likely to move quickly to lightly regulated foreign jurisdictions. Privately, they added that they considered the CFTC, with its slim bench of professional talent, cozy relationship with Chicago traders, and lack of perceived heft in the banking system, to be the least suitable Federal agency to oversee swaps trading, particularly among commercial and investment banks.

Amidst as great angst between governmental witnesses as I ever witnessed, the most sober observation was that of Chairman Greenspan. "I have no doubt derivatives losses will mushroom at the next significant downturn as will losses on holding of other risk assets, both on and off exchanges," he observed. But in an understated assessment, he further noted that swaps contracts involved a "wholly different type of market process" than trading in

${ }^{4}$ For statement and bill, see the Congressional Record 140.2 (January 26, 1994), statement 29.Available at http://www.gpo.gov/fdsys/pkg/CREC-1994-01-26/html/CREC-1994-01-26-pt1-PgH54.htm. 
commodities, the pointed implication being that, in the Federal Reserve's judgment, the capacity of the agriculture-oriented CFTC to oversee financial markets was a stretch. ${ }^{5}$

Confronted with unprecedented public splintering of financial policy views within the Executive branch, I tried to broker a consensus memorandum of understanding that each could approve. Initially suggesting a "standstill" approach close to that of the Federal Reserve and Treasury and later embracing several perspectives of the CFTC, I developed a series of draft approaches to resolve differences in an effort to avoid legislative intervention. I have never known a committee of Congress to ever undertake the refereeing of Executive branch differences in this manner, but I felt it important that the government speak with one voice when the prospect of riling markets and moving a multitrillion dollar market abroad was at issue.

Amongst the regulators, it was three to one, with Treasury, the Federal Reserve and SEC accepting some of the concerns of the CFTC that I had pressed into a final (fourth) draft approach. I thought we were close to agreement but the three exceptionally frustrated banking and securities regulators balked at the "standstill" constraints Chairman Born ironically insisted be placed on their regulatory discretion as a condition of her backing off the processes the CFTC had set in place.

Since issuing the 1993 study on derivatives and introducing my first bills on the subject in 1994 and 1995, I had been concerned with the challenges of derivatives clearing, but was reluctant to insist prematurely on utilization of clearinghouses until the legal risks that the Federal Reserve and Treasury enumerated could be legislatively resolved.

As the decade ended, the Agriculture Committees of the Senate and House, which have jurisdiction over the CFTC, generated a bill that came to be known as the Commodity Futures Modernization Act (CFMA) of 2000. The bill resolved the legal certainty issue that applied to existent swaps contracts and authorized the establishment of clearing facilities to be regulated exclusively by the CFTC. Based on Congressional precedent and overlapping jurisdictions, the bill was sequentially referred to the Senate Banking Committee and the House Committee on Banking and Financial Services.

On the Senate side, Chairman Phil Gramm demanded that certain products bought and sold by large institutions be exempted from case-by-case oversight but acquiesced to SEC chairman Arthur Levitt's insistence that his agency be provided compensating powers. For the first time, the SEC was thus provided anti-fraud and anti-manipulation authority over all

\footnotetext{
${ }^{5}$ See Testimony by Alan Greenspan, Chairman, Board of Governors of the Federal Reserve System, before the Committee on Banking and Financial Services, U.S. House of Representatives, July 24, 1998. http://financialservices.house.gov/banking/72498fed.shtml
} 
derivatives contracts and given insider trading enforcement powers over all securities-based swaps agreements.

On the House side, I concluded that the CFMA, while a flawed bill, could, if properly amended, provide a framework to establish clearing facilities overseen by competent federal regulators. The Banking and Financial Services Committee would not concur, I indicated, with House consideration of the bill unless the Federal Reserve and Treasury in addition to the CFTC were properly empowered to authorize and oversee swaps clearing facilities.

Opposition quickly developed within and outside the Congress to the clearing option I pressed. Various Wall Street lobbying coalitions, principally the Ad Hoc Coalition of Commercial and Investment Banks, worked with members of the Agriculture Committee to object to the prospect of what they feared would be comprehensive Federal Reserve or Treasury supervision of clearinghouses. But I held firm and this provision with balancing empowerment given later in the legislative process to the SEC was placed in the CFMA of 2000.

The importance of swaps clearing cannot be underestimated. The greatest challenge in derivatives markets is to get a handle on individually tailored products sold in multicountry, multiparty markets. The creation of clearing facilities allows for the prospect that swaps, including credit default instruments, can be pressed into a regulated environment where various standards can be insisted upon as a condition of institutional participation. The value of derivatives transactions in notional terms is more than the combined gross domestic product (GDP) of all countries of the world. But when netted out, that is, cross discounted with counter parties, multitrillion dollar figures can in some cases be discounted by factors of 100 or more, depending on the contract design and individual party relationships.

Clearing facilities not only serve as a grease to make the engine of finance work more fluidly, they also provide incentives for market standardization and a hook to bring governmental oversight to market participants, including non-banks and foreign firms.

The concern for derivatives clearing in troubled times also led me to introduce over a series of Congresses a bill to allow a timely netting of derivatives contracts in the event a firm enters bankruptcy. Without a special exemption under our bankruptcy laws for orderly netting of derivatives contracts, these contracts could be caught up in months, perhaps years, of bankruptcy turmoil, potentially spurring a bankruptcy contagion. Legislative language I had crafted on this point was originally accepted on the House side as part of the CFMA of 2000 but subsequently stripped at the insistence of the Senate Judiciary Committee. I finally got the language passed half a decade later as a provision in an otherwise controversial bankruptcy reform act.

Whether it was wise to let Lehman Brothers go under - and many on Wall Street and a number of economists now believe the government erred in not intervening or working more 
assiduously to incentivize a merger partner - and whether the methodologies undertaken to shed certain investment assets of Lehman Brothers resulted in fair asset distribution, the exemption just referenced freeing derivatives contracts from becoming tied up in lengthy bankruptcy proceedings coupled with the flexibility provided by the clearing capacities authorized in the above mentioned amendments to the CFMA take pressure off the government to prop up financial firms facing insolvency challenges.

\section{The Responsibility of Regulators}

What I am suggesting that again may be counterintuitive to many is that while clearing facilities were not administratively in place, the statutory framework nevertheless existed during the recent financial meltdown for mutualization of derivatives counterparty risk, supervision of derivatives clearing, and for resolution and clearing of derivatives contracts involving insolvent entities.

The CFMA is a law that critics have properly focused on as a problematic statute. But the most problematic aspect of the law relates to its implementation - the failure of the SEC to implement the anti-fraud, anti-manipulation, and insider trading authority that it was accorded and, most importantly, the failure of relevant federal regulators to press on a timely basis the creation of clearing facilities for swaps.

These failures do not mean that the Senate Banking Committee was correct to insist in negotiations on the CFMA that discrete derivative products developed and traded exclusively between large, federally regulated banking and securities firms should be exempted from direct oversight. Nevertheless, it was the failure to implement provisions authorized by statute that proved to be more systemically consequential than the constraints the law placed on regulatory capacity to review individual credit default arrangements.

A fair question is why, until the crisis, was there so much reluctance of the four regulatory bodies - the Federal Reserve, the Treasury, the SEC and the CFTC - to implement fully authorized capacities.

The CFMA removed the cloud of legal uncertainty that would otherwise have hindered utilization of swaps clearinghouses and allowed any resulting clearing to be regulated federally. Yet, for most of the first decade of the $21^{\text {st }}$ century, a period in which derivatives markets swelled to glittering heights, industry intransigence coupled with regulatory turf concerns impeded the development of swaps clearing facilities. Powerful financial institutions preferred to market individually tailored product approaches where margins could be expected to be high rather than standardized, more easily clearable products.

It wasn't until the spring of 2009, based on concerns expressed by the New York Federal Reserve the summer before, that multiparty derivatives clearing institutions finally began to get off the ground with the chartering of a special purpose Federal Reserve supervised 
clearing bank designed to serve large financial institutions, and CFTC-supervised facilities to serve non-bank traders and smaller financial entities.

The refusal of the Executive branch in the last months of the Clinton Administration and early Bush years to advance mechanisms to mutualize credit risk with standardized products and establish clearing facilities for derivatives contracts is one of the greatest judgmental failures in the history of regulation.

Derivatives aside, what is principally but by no means exclusively at issue on the regulatory front today are two failures and the manner each informs the question of whether and how to reorganize regulation of finance. The first failure was inadequate regulation of housing finance, particularly Fannie Mae and Freddie Mac, and inadequate oversight of the worldwide marketing and insuring of mortgage portfolios that presumably were designed to reduce cost to home buyers and risk to financial institutions. The second was the green light given large financial institutions to radically increase their leveraging ratios. The first mistake precipitated the financial crisis; the second deepened and lengthened it.

For over a decade, the Federal Reserve warned Congress to no avail of problems inherent in Fannie Mae and Freddie Mac regulation and market dominance. But just as Congress and to a partial degree the Treasury ignored the Federal Reserve's judgment on housing GSEs perhaps influenced by the favors and campaign contributions Fannie Mae and Freddie Mac showered on the Hill - regulators failed to comprehend the macroeconomic as well as criminal implications of the reports of mortgage fraud filtering in from around the country. Many members of Congress heard anecdotally about fraud in the mortgage brokering industry in their districts and brought their concerns to the attention of regulators in hearings and meetings, especially during the late 1990s.

Warnings about the existence and implications of mortgage fraud and the need for viable swaps clearing facilities were largely ignored. The pervasive attitude seemed to be that since so many bright people were involved in money center finance and since finance was one of the few areas of commerce that America was competing well in around the world, traditional concern for prudential capital standards and more contemporary concern for derivatives processing could be dropped in favor of benign corporatist neglect.

Just as the Treasury and Federal Reserve were disinclined to object to the thin layers of capital which had seemed to be successfully managed by money center banks, so the SEC, despite the green light it gave to greater investment bank leveraging, was disinclined or lacked sufficient financially trained professionals to implement the anti-fraud, antimanipulation, and insider trading enforcement powers over securities-based swap agreements provided it under the CFMA.

While the CFMA exempted credit default swaps from being considered securities under federal securities laws, it neither exempted principal market participants nor all aspects of the 
derivatives market from regulation. And it never exempted the banking regulators, SEC, or state insurance departments from responsibility for institution viability, which necessitates a company-wide assessment of all the risks undertaken by a financial firm under a regulator's purview.

Regulator accountability is particularly vexing in the context of swaps because definitional boxes are not neat. The jurisdictional concerns of those accountable for overseeing insurance, banking, commodities, and securities activities overlap.

For instance, in the case of AIG's London office where so few lost so much, its insurance regulator (the New York Insurance Department) should have understood that just as a casualty insurance company must keep deep reserves and/or have comprehensive reinsurance to protect against hurricane claims, AIG should have had deeper reserves to protect against man-made financial disasters. Likewise, Treasury's OTS, which oversaw AIG's London operations due to a British law requiring a national regulator to assert responsibility for foreign financial firms in British jurisdiction, should have understood that the company was massively over-leveraged relative to the risk it was assuming.

AIG had a lucrative business as long as there were no adverse economic occurrences. But adverse things do happen, and while both the state insurance regulator and the Treasury Department might have been handicapped in not being able to review the micro dimension of a particularly incendiary financial product, they should have had the macro judgment to recognize the nature of the business and the systemic risk it posed.

There is an old saw to the effect that success has a thousand chest thumpers while failure has no one raising a hand. With regard to the collapse of AIG, it is the New York Insurance Department and the Treasury Department (OTS) that held the door open while a small group of AIG traders in London cracked the public safe and Congress blinked as the getaway car sped past. In the aftermath, it was the decision of the Treasury Department to increase substantially taxpayer liabilities to protect fully AIG counterparties (investment and commercial banks, foreign and domestic) and provide surprising shelter for AIG shareholders.

Collective responsibility exists for the current crisis but the collectivity of it all should not limit individual institution accountability. Regulators simply cannot shirk responsibility for institutions failing under their jurisdiction.

Regarding Congressional accountability, it is instructive to review the House debate that occurred in 1993 and 1994 on the bill creating the regulatory apparatus to oversee Fannie Mae and Freddie Mac. As the only member of the Banking Committee to vote against the bill in committee, I led a quixotic debate on the House floor against the measure. A review of that debate as well as of the comprehensive approach I proposed in a following Congress to restrain the multibillion dollar perquisites provided annually to these two GSEs might be 
helpful in revealing the array of egregious advantages Congress handed no other corporations of any kind in American society. ${ }^{6}$

To date, the major systemic issues that will cost taxpayers significantly will come outside of the traditional bank regulatory system. Commercial banks, particularly money center institutions, have suffered significantly and several large and a number of smaller banks and S\&Ls have failed in this crisis. But if the economy continues to recover, it looks as if virtually all public funds, including Troubled Assets Relief Program (TARP) resources, infused in commercial banking will be returned with interest. The Federal Deposit Insurance Corporation (FDIC) has lost enormous resources in dealing with a number of failed banks but these funds were derived from assessments over the years on banks rather than taxpayers.

It is in three institutions - Fannie Mae, Freddie Mac, and AIG - where public funds are least likely to be recovered. Losses embedded in these institutions underscore the housing and mortgage product dimension of the financial implosion. If Congress's industry-pandering approach to regulation of Fannie Mae and Freddie Mac had been structured more prudently; if banks, securities and insurance companies had come under more restrictive leveraging guidelines, particularly in the trading of derivatives products; if swaps clearing facilities had been created and vigilantly regulated; and if mortgage fraud had been more diligently pursued and mortgage portfolios properly valued, the depth and consequences of the current financial crisis could have been substantially mitigated.

Foreigners often wonder why the U.S. does not go to a single regulatory model. But total simplicity isn't always a panacea. As events have shown, the British experiment with a single regulator has produced results more disastrous than ours. Indeed, the most decentralized part of our regulatory system - state regulation - has in this crisis held up better than national regulatory bodies. Unlike Europe, we are a geographically robust society with a federal political structure and tradition. Just as in our federal political system, there are regulatory counterparts at the state level.

The vastly more prudential approach taken by state regulators of community banks over the last decade informs review of the recent crisis because of the contrast it provides with the

\footnotetext{
${ }^{6}$ There are many examples of the extraordinary reach of Fannie Mae and Freddie Mac on Capitol Hill. Three personal anecdotes are illustrative: Late one week, I circulated a battery of amendments to Fannie Mae and Freddie Mac legislation that would have radically reformed their manner of operating. The next Monday I received phone calls from three of my party's leaders in the House with the same message: the approach, even if it got out of committee, would not be scheduled for consideration in the House. The same day an exMember called to underscore how much he shared the views of House leadership, but after going down his talking points, he burst out laughing to tell me how fortuitous it was for him that I had proposed the reform initiative. Upon learning of its existence, Fannie Mae management, which had extensive ties to Democrats on the Hill, decided they needed more Republican assistance and offered my excolleague what he described as a much appreciated retainer to join their stable of lobbyists. Several weeks later I received a letter from the mayor of Washington, D.C. objecting to my approach, even though one of its provisions would have removed the unprecedented exemption the two housing GSEs have to paying state and district income taxes, a change in law that would have provided multimillion dollar benefits to the budget of the District of Columbia as well as every state in the country.
} 
regulation applied to our largest national banks and with the errors state authorities were accountable for during the $(\mathrm{S} \& \mathrm{~L})$ crisis a generation ago.

The S\&L crisis was initially triggered by an inflation-driven increase in the cost of funds for institutions that borrowed short and lent long. It was then compounded by capricious regulation and law making in a small number of states like California, Texas, Louisiana, and Arkansas, where instead of insisting on recapitalization, state authorities allowed institutions to attempt to work their way out of insolvency by providing an unprecedented right to use federally insured deposits to make direct investments. These investments generally proved misguided, thus deepening losses that had to be picked up by an inadequately capitalized federal fund that had to be bolstered with taxpayer resources. Relatively small institutions caused surprisingly large public losses.

By contrast, the current financial trauma has been alleviated rather than accentuated by interest rate changes and disproportionately involves one group - nationally regulated institutions characterized by bigness. The level of imprudence in the regulation that precipitated the worldwide financial crisis was in direct proportion to size of institutions regulated.

It is conjectural whether any financial institutions should be considered "too big to fail" and an open question whether some are "too big to manage." But what is clear in the last decade was that mega-banks were "too big for Washington to understand."

Community banks, on the other hand, are in a relatively stronger position today for a number of reasons, one being a singular reliance of state regulators on prudential capital standards.

For years I used to be labeled a "capital hawk" because I argued that large banks should be subject to the same capital standards as community institutions. To apply looser standards to the big not only increased systemic risk, it incentivized the movement of capital from more prudentially capitalized institutions to banks with comparatively smaller capital cushions. But for decades there had been an assumption in Washington, magnified during the Bush years, that because money center banks had ready access to capital markets and were run by people of enormous talent able to limit industrial risk with diverse lending portfolios and operating options, they ought to be allowed to leverage to a far greater extent than community banks.

Today, if one were sitting on the moon and observing the multitrillion dollar contraction in world economic activity precipitated in no small measure by the biggest American financial institutions, it would appear self evident that institutions that are so large as to be able to systemically jeopardize the economy should be required to maintain capital standards not only equal to but stronger than non-systemically challenging ones. When the public welfare 
has been so extraordinarily damaged by the lure of leveraging, new rules need to be written. The game should not be replayed the same way.

Industry participants are prone to contend that, in an emergency, liquidity in a financial institution matters more than capital. There is certain logic to this proposition in that banks have an everyday challenge to manage liquidity demands. But if a bank has solid capital, it generally has ready access to liquidity through inter-bank borrowing, or the pledging of assets to the Federal Reserve or a Federal Home Loan Bank, or through public or private equity offerings. On the other hand, if it is perceived to lack sufficient capital to cover losses, a run of substantial magnitude can occur on an institution in a blink of an eye. There is no substitute for the strength that tangible equity capital provides.

The public interest must be the preeminent regulatory concern, but it is a myth that all public policy concerns are necessarily at odds with shareholder interests. While greater institutional leveraging in stable times can spur per share bank stock returns, the reverse can be the case in volatile circumstances. When financial traumas occur, the economy can contract and the shareholder and, more importantly, the public can be on the line for losses of a vastly larger magnitude. This is why the use of mathematical models to help assess risk has to be considered exceptionally useful but only with the understanding that the lesson of this past crisis is that care must continually be taken to insure that such modeling augments rather than replaces reliance on traditional capital standards.

The big picture is that intense competition is underway for leadership of international banking. In order to reestablish worldwide financial preeminence, protect the taxpayer, and reclaim investor confidence, the principal responsibility of regulators must be to constrain the lure of leveraging. The case for deferring to a management that may prefer to operate with minimum levels of capital is frail to nonexistent.

The tarnishing of the reputation and leadership of the United States that has had such extraordinary repercussions in all fields of commerce and geopolitics must be repaired.

\section{Congressional Initiatives}

Whatever regulatory scheme is in place at any point in time, the challenge for the Executive and Congress should always be to avoid populist irrationality and, at the same time, steer clear of interest group captivity.

There are a number of approaches that can be taken to organizing financial regulation, including various ways to consolidate commercial bank supervision. Clearly the Washington alphabet soup institutions - the Fed, SEC, CFTC, OTS, OCC, and FDIC - that evolved over many decades present a confusing picture. The existence of too many regulators can cause a 
lack of accountability and at the same time increase the capacity of private sector parties to game the system through regulatory arbitrage - the movement or implicit threat of movement of a financial institution to the least intrusive regulator.

The central reform initiatives that demanded the greatest attention of Washington policy makers in 2010 were the need to press forward with prudential oversight, including strong capital standards, in systemically significant financial enterprises, non-bank as well as bank; to utilize more extensively clearing facilities for derivative contracts; and to develop further emergency approaches to resolving problems of failing financial institutions of all kinds, preferably without infusions of taxpayer resources.

Congress's approach in 2010, the Dodd-Frank bill, gives systemic risk authority to a committee chaired by the Treasury. The determination to establish a committee to oversee systemic risk mirrors to a large extent a framework bill I introduced in the mid 1990s. H.R. 20, the Risk Management Improvement and Derivatives Oversight Act of 1995, would have created an interagency Federal Derivatives Commission to be chaired by the chairman of the Federal Reserve, consisting of the federal banking agencies plus the SEC and CFTC. The proposed Commission was empowered to establish strong capital standards and limits on leverage and to advance common rules related to accounting, disclosure, sales practices, including appropriateness, and such other regulatory actions the Commission deemed relevant to the supervision of financial firms engaged in derivatives activities. The dual goal was to establish cross-industrial commonality of standards and collective Executive branch accountability for these standards.

H.R. 20 also provided relevant regulators the legal authority to net out or otherwise deal with clearing contracts of failed financial institutions. The bill required the Derivatives Commission to provide risk management and derivatives activities training for regulators and called on the Federal Reserve to lead in international negotiations aimed at seeking commonality of standards worldwide. The bill included a host of other provisions, including an amendment to the Federal Deposit Insurance Act stipulating that engaging in derivatives activities with inadequate technical expertise could be deemed to constitute "an unsafe or unsound" banking practice.

As the newly designated chairman of the Banking and Financial Services Committee, I had hoped that H.R. 20 would be the principal agenda item for the committee in the $104^{\text {th }}$ Congress. But because the bill fetched vibrant industry and conservative opposition and could not garner support from either the Clinton administration or liberals on the committee, it could not muster sufficient momentum for Congressional movement at the time.

The Dodd-Frank approach calling for the Treasury to head a comparably empowered committee is a thoroughly constructive initiative although the Federal Reserve would have 
been a more suitable, less political choice to chair regulatory coordination. No matter how able a particular Secretary of the Treasury may be at any moment in time, the Treasury by its nature is at the epicenter of politics. The Federal Reserve, on the other hand, is an institution ensconced in the art of economics. Politics is circular; repetition is the norm. Economics is linear; experience can more readily add to judgment.

These distinctions are relevant for if the regulatory policies of the prior two presidencies are a guide, it would appear that the Treasury under both political parties has an institutional predilection to shower discreet, outside the public glare favors on Wall Street during presidential election years. The Federal Reserve has likewise at times been overly deferential to Wall Street concerns, particularly relating to leveraging, but because mistaken judgments have generally been more ideological than political, lessons are more easily grasped and changes in approach more readily implemented.

Chairman Bernanke manages the most impressive assembly of economic talent in the world and has ready access to the expertise of America's relevant academic and financial institutions. Most importantly, the Federal Reserve's quasi-independent status positions it to be more above politics than any other governmental body. This circumstance alone is worth its weight, figuratively and non-metaphorically, in gold.

As this financial trauma has shown, the Federal Reserve has the greatest financial discretion to act in an emergency of any governmental body. It has multitrillion dollar pockets and the legal discretion to move with alacrity. By contrast, Treasury's very name can be a misnomer. It has more regulatory than financial discretion. It has no money unless Congress first acts.

While the Dodd-Frank bill provides certain new powers to the SEC and CFTC, greater consideration could have been given the prospect that these two regulatory cousins be part of a three-way merger, with the third party being an infusion of a substantial number of new professionals with backgrounds in math, economics and accounting. The CFTC has impressive leadership at the top and extraordinary jurisdiction but a staff that has historically been responsible for non-financial markets. Size and personnel-wise it may not be large and experienced enough to manage the responsibilities it has been given. The SEC is also well led today and has an estimable history, much bigger staff, and an impressive record of shareholder protection, but it has an analogous problem of the CFTC - the existence of surprisingly few professionals devoted to oversight of the securities industry, let alone all the other areas of finance that have grown so substantially in recent years.

The Byzantine Congressional hurdle that blocked a consolidation approach in 2010 relates to reluctance of powerful Capitol Hill figures to cede jurisdictional authority of committees upon which they sit. The exchanges in Chicago, for instance, are active political contributors 
and want to maintain their cozy relationship with the CFTC and their close ties to the agricultural committees of Congress. The political key is to provide a way for the various committees of Congress to keep in place jurisdiction over the activities they have today while at the same time providing greater depth and enhanced independence to consolidated administrative units within the Executive.

Appropriately, under Dodd-Frank, the Treasury's OTS has been merged into its OCC. Wisely, mortgage lenders are required to keep a 5 percent stake in loans they sell into secondary markets. And, controversially, banks are allowed to invest 3 percent of their capital in private equity and hedge fund activities.

This investment provision is tangentially reminiscent of the commerce and banking "basket" breach that the Federal Reserve advocated in the mid 1990s but is substantially more constrained. Investments are limited to 3 percent of fund value as well as 3 percent of capital. In theory, this provision touches on the concerns that former Federal Reserve Chairman Paul Volcker has articulated about banks doing proprietary trading and potentially entering speculative markets. While the double 3 percent limits are designed to keep equity investing as a de minimis part of banking, the larger theoretical issues will come more to the fore if and when these percentage constraints are allowed to increase. This "nose in the tent" prospect is likely to garner extensive attention in the years ahead with proponents arguing that proprietary trading wasn't a major factor in the housing related losses where the taxpayer faces the biggest liabilities today. Nevertheless, at increasing issue is the question of whether banking should exclusively be structured as a financial services industry or an enterprise that also is allowed to compete, even become conflicted with its customers.

The functional fate of the $\$ 6.5$ trillion behemoths, Fannie Mae and Freddie Mac, where the Congressional Budget Office predicts that taxpayer are set to lose $\$ 380$ billion, perhaps more, remains unresolved. And the corporate future of AIG is still unclear.

One of the reasons that concern is so great over the government's responsibility in the failure to prudently regulate Fannie Mae, Freddie Mac, and AIG is that the subsequent decision to fully back the liabilities of these three institutions tripwired counterparty bailouts not only of Wall Street firms but foreign banks. The perspective that is hardly noted abroad because of the anger that has developed against American financial leadership is that as a consequence of the manner the Treasury Department chose to assist domestic counterparties, the bailouts of Fannie Mae, Freddie Mac, and AIG produced the largest foreign assistance program since the Marshall Plan.

The principal difference between President Truman's approach in 1948 and Secretary Paulson's sixty years later is that the Marshall Plan was in reaction to the need to build up 
European economies in the wake of Nazi aggression and the imminent threat of Soviet imperialism. The Paulson Treasury decision also had significant international implications, but it was not triggered by adversaries. Rather, a breach in the economic order was precipitated by aggressive American private sector financial strategies unchecked by prudential regulatory judgment. Perhaps cognizant of its own regulatory accountability as well as concern for an international financial contagion, the U.S. Treasury responded to the growing financial fire by calling on the taxpayers to hold as harmless as possible those affected by these strategies, at home and abroad, as well as those accountable for them.

Historical perspective is difficult to apply to recent events, but it is hard to visualize any other country in the world bailing out American banks investing in faulty foreign financial instruments. Under agreement, every government is responsible for its domestic bank traumas. Before this crisis, no one ever suggested that another country should be responsible for the difficulties of banks outside its sovereign jurisdiction or common market framework.

It is understandable that Wall Street salesmanship of improperly valued mortgage portfolios should outrage foreign institutions. But at a minimum, one would think the U.S. taxpayer would get a little credit abroad for unwittingly bailing out foreign banks, and that Wall Street should realize that, in exchange for the massive public assistance it received, the taxpayer has compelling reason to unequivocally demand that systemically consequential institutions operate in the future with more prudence, fewer conflicts, and less leverage. A requirement that mega financial entities maintain strong capital cushions is a small price to pay for those institutions that cost so many American jobs, so much taxpayer money, and so much loss of national reputation.

With regard to Fannie Mae and Freddie Mac, Congress decades ago had legislatively provided a backstop not given any other publicly traded companies - a right to draw down $\$ 2.5$ billion from Treasury in an emergency. It was this right plus a host of other advantages given these GSEs that allowed them to borrow from the public for so many years at close to Treasury rates. But, prior to this crisis there were no grounds to believe that these two entities could tap into the Treasury nearly a hundred times more than these legislated commitments. Every sophisticated bank in the world knew our law and its precise limits.

This circumstance doesn't mean that the Treasury was wrong in its determination to move quickly to stabilize the financial system after it compelled the demise of Lehman Brothers. But fairness judgments must also come into play. Should shareholders of failed institutions enjoy taxpayer protections? Should financial discounts have been more actively pursued with the counterparties of AIG, Fannie Mae and Freddie Mac to protect the taxpayer? Should contingency plans and procedures of various kinds have been set in place, especially those authorized by statute, prior to rather than after financial problems erupted? 
The questions that surround both the causes of the financial system's unraveling and the methodologies of dealing with individual institution failures underscore why it is so troubling that big institutions were allowed to leverage so excessively in the Bush years and so cavalierly given aggressive investment rights during the Clinton administration, including the discretion to invest in the stock market as part of derivatives hedging strategies, as if the failure a few years earlier of long term capital management and earlier yet of S\&L investment excesses were not alarming precedents. It is why there is such concern that large financial institutions not be given legislated powers that misalign their business interests with those of their customers and that of the public.

Over the last several decades, for instance, the committees of jurisdiction in the financial overhaul debate were lobbied not to reform an obscure charter for industrial loan companies (ILCs). Authorized to be issued in only a half dozen states, ILC charters allow parties to escape Federal Reserve rule making and/or Treasury supervision. They provide a back door avenue both to merging commerce and banking and to exercising banking powers without the oversight that goes with traditional banking. Companies that hold ILC charters should be placed under the Bank Holding Company Act. Such an approach would force the divestiture of firms that breach commerce and banking and place any financial firms holding the charter under the jurisdiction of the Federal Reserve.

Having attempted on numerous occasions to advance such an approach, I know how influential a few interest groups and a few legislators can be on the other side of the issue. So, if Congress considers this approach too politically uncomfortable but finds it compelling to advance a compromise that goes beyond the three-year moratorium on new ILC charters that the Dodd-Frank approach establishes, it could permanently preclude the issuance of further charters, place limits on the size of existing ILCs, restrict charter transferability, and insist on backup Federal Reserve regulation for all.

\section{Internet Gambling}

Oddly, the most challenging issue in finance today, where capricious public policy could most jeopardize the viability of financial institutions, their customers, and the public at large, was outside the jurisdiction of the recent financial overhaul bill. The subject is Internet gambling. It behooves the public and the financial community to think through whether it is wise to uphold or eviscerate the last statute I passed as a Member of Congress, the Unlawful Internet Gambling Enforcement Act (UIGEA) of 2006. Gambling interests have weighed in on committees of jurisdiction in Congress in a considered effort to overturn or, at a 
minimum, delay the implementation of its prohibition on credit card companies, banks and other financial intermediaries from processing or facilitating payments to Internet casinos.

The prospect of Internet gambling suddenly mushrooming in America hinges on a public decision that relates directly to what kind of society we want to have. Einstein is said to have observed that the only real miracle is compound interest. Failure to save, on the other hand, can have compound social implications. Internet gambling is an analogue to predatory lending. It is a predatory savings practice with "deposits" going to off-shore gambling institutions operating in violation of a host of state and federal laws rather than into an individual retirement account (IRA) or federally insured savings account.

If legalized, Internet gambling could grow rapaciously and rob far more Americans of the capacity to buy and maintain a family home than all the predatory lenders combined. What everyone has missed in the debate over UIGEA is that there is a quantum distinction between bricks and mortar casinos and Internet gambling. Internet gambling brings the casino to the college dorm, the work station, the kitchen and bedroom of the American home. It has the potential to become the most omnipresent and invasive financial industry in the world, competing for the disposable dollar with the corner shoe store and community bank as well as Wall Street. Yet Internet gambling does not involve the making, distributing or facilitating of any meaningful services or products.

Advocates of legalizing Internet gambling have come to Congress and suggested that it could provide a new federal revenue source. This is true if one assumes that a massive expansion of Internet gambling will have no effect on other governmental revenue. But such reasoning is nonsensical. As Internet gambling revenues go up, tax receipts from service industries tied to finance, manufacturing and retail marketing go down, while the need for expanded social services caused by business and family bankruptcies escalate.

Yet because UIGEA puts a modest enforcement obligation on banks, the American Bankers Association (ABA) so chafes at the prospect of an exaggerated new regulatory burden that it is willing to play Russian roulette with the American economy and the role of banks in it. The prospect that immature regulatory carping could lead to an unnecessary crippling of our economy and social fabric is real.

\section{Lobbying}

There is an assumption everyone understands that lobbying organizations are designed to represent the parochial rather than the national interest. But in my years in Congress I found that now and again lobbyists could be as confused about their own vested interests as legislators can be about the national interest. 
Gambling interests, for interest, have huge behind the scenes influence in American politics. Could it be that when bank lobbyists and Internet casino lobbyists come down on the same side in trying to block anti-Internet gambling legislation and the rules to enforce it, that one or the other is being duped?

This confusion also seemed to be the case with regard to the ABA's objection to placing one of the banking industry's most sophisticated competitors - Industrial Loan Companies under the Bank Holding Company Act.

Could it be that one reason Merrill Lynch got in such difficulty is that its multibillion dollar ILC operated without Federal Reserve oversight and without comparable rules applying to comparable financial activities of traditional banks?

Could it be that allowing certain foreign institutions - commercial as well as banking - to gain entry into American finance with advantaged ILC charter rules jeopardizes other parts of American banking and commerce as well as basic systemic stability?

But the real trauma of lobbying is less the problem of bewildering misdirection and more the consequences that unfold when industry concerns are pitted by design against the public interest. Here it is a myth to assume in finance that one party is more aligned with the public interest on Capitol Hill than another. Interest groups shower attention on both sides of the aisle on committees of jurisdiction, generally with more favors thrust on members of whichever party is momentarily in the majority. Over my time in Congress - 18 years in the minority and 12 in the majority - the more liberal party had the close attention of GSEs, S\&Ls, and investment banks. The more conservative party was more attuned to commercial banking. Sometimes competitive advocacy would spring up with rivalries generally advanced at the top where, largely unnoted by the public, senior members of committees are asked to raise substantial funds to assist party campaign treasuries ${ }^{7}$ in socalled "leadership" political action committees (PACs) which they control. Unless one doesn't believe in human nature, a citizen might surmise that gifting to member-controlled PACs might precipitate quid pro quos of an even greater magnitude than direct campaign contributions.

\section{Keynes vs. Friedman}

In the wake of what some will suggest is a legislative over-reaction in 2010 to the financial meltdown and what others will consider the taking of inadequate fiscal and regulatory steps,

\footnotetext{
${ }^{7}$ On issues like abortion rights and the Iraq War, I was philosophically out of step with my party but my position as chairman of the Banking Committee was more jeopardized by refusal to play the political action committee funding game than any stance on any issue.
} 
the question remains whether a roller coaster double or even triple or quadruple dip recession is ahead, and whether the banking system is stabilized enough to weather the challenges and be in a position to put bounce back into the economy.

American economic viability is based on a competitive financial system which in turn is dependent on how judgments are reconciled between the two principal economic paradigms of the twentieth century - that set forth by John Maynard Keynes and that suggested by Milton Friedman.

Philosophically, Keynes was never as liberal as his adherents often assume. He believed in fiscal intervention to spur productive potential in an economic downturn or national emergency. At the same time, he argued that debt should be paid back after an economy stabilizes. Friedman, for his part, also believed in economic stimulus in faltering times, but he would rely more on interest rate cuts than spending increases and he maintained an abiding conviction that even more important than a budget in balance was that government not grow too large relative to the size of the economy.

What is new in the current Keynesian/Friedmanesque debate is the manner in which the Federal Reserve has led not only with traditional monetary policy tools but with innovative techniques to infuse more money into the economy than Congress's fiscal approaches provided. What is also new is that most of the Federal Reserve's stimulus and some of Congress's so-called TARP funds will be paid back, with interest. As, or more precisely, if the economy recovers, an unprecedented amount of "borrowed" resources could be returned on rather short notice to the government.

The contrast of Keynes vs. Friedman on economic matters mirrors the contrast of liberals vs. conservatives in politics. Fiscal and monetary policy can move in tandem to spur or constrain an economy. Likewise, the two can move in contrast. Today, both approaches are designed to stimulate. Big deficits at the state as well as national level are coupled with low interest rates. Whatever judgmental tacks are considered in the future will be made in a setting in which options for policymakers become narrower because demographically the population is aging; because the modest recovery underway may be insufficient to significantly bring the unemployment rate down; because debt-to-GDP has grown to troubling levels; because for the first time problems in governance at state levels could exacerbate problems at the national level and vice-versa; and because, for whatever reasons, political winds shift.

At some point, sparked rationally or perhaps irrationally, triggered by a small local or big international event, confidence can stutter and the recession just ended could reignite. 
Hence a crucial challenge is the maintenance of social cohesion. Now is not a time to polarize. We can vigorously disagree as a people on what the most appropriate governmental action should be and perhaps credibly shift policy gears, but we should never abandon the pursuit of common ground. Little could jeopardize the economy more than a governance breakdown.

\section{The "Who" and "What" of Regulation}

As important as the locus of regulation is, it is vastly more consequential to concentrate on the question of the independence and judgmental capacities of those regulating than the design of the institutional boxes where authority is placed. The "who" and "what" matter more than the "where."

Here I want to postulate a premise that goes against the dominant genetic bias of Washington. Experience tells us that there is a difference between linguistic and numerical capacities, and scientists inform us that discrete activities are concentrated in various parts of the brain - creative instincts in the right lobe; numerical competency in the left.

Accordingly, in reference to neuron activity rather than partisanship, it may be that the failure of regulation in the last decade relates in part to the disproportionate dominance of rightbrainers in positions of financial oversight. Financial regulation, after all, is more about understanding numbers and their implications than words and their meaning.

In this regard, there is a difference in education and training of individuals with varying interests and aptitudes. From a nurture perspective, the most appropriate regulatory background for nature's linguistically oriented right- brainers is law school. Regulatory bodies need quality attorneys trained in process considerations to insist on compliance with law. But the regulatory tragedy of the decade is not only the lack of regulatory personnel but the lack of balance in the background of regulators. A paucity of attention had been given to complementing the legal expertise of many regulators with left -brain talent - certified public accountants (CPAs), economists, and mathematicians.

It is hard, for instance, to imagine how a quality CPA could have walked into Bernie Madoff's office and not demanded to follow the money, to know where assets were and how they could be verified. It is hard to visualize a sophisticated economist would not have recognized that AIG did not have sufficient reserves to guarantee either the magnitude or the integrity of the credit default insurance it was selling. And it is hard to see how an experienced mathematician could have reviewed many of the mortgage portfolios Wall Street firms hawked and concurred with the triple-A ratings applied.

Uniquely, lawyers and CPAs represent professions which have precise obligations to the law which go beyond their obligations to employers and clients. A lawyer is ethically bound by his or her profession to represent a client to the fullest extent but remains an officer of the court and is ethically bound not to lie or commit a felony to protect a client. A CPA's 
obligations go even further. While a lawyer may, and in some cases must, be silent about a client's circumstance, CPA attestations imply that obligations to reflect a truthful picture to the public trump concerns for the interests of employers or clients.

Risk factors are inherent in financial numbers, but to avoid garbage-in, garbage-out modeling, the quality of loans and their relationship to macroeconomic vulnerabilities must be prudently assessed. Mathematicians must work with economists using numbers scrubbed by CPAs to create financial products that lawyers can attest to, and regulators can conclude don't increase institution or systemic risk.

\section{A Final Perspective}

The Dodd-Frank legislation that passed in 2010 maintains the framework of Glass Steagall as modified by Gramm-Leach-Bliley. Several changes in the alphabet soup of regulatory bodies occurred. The most irresponsible Treasury regulator - the OTS - was eliminated and two new authorities were created. A consumer protection bureau was thrust on a reluctant Federal Reserve and a committee of regulators was empowered to oversee systemic risk. The oversight jurisdiction of both the newly authorized consumer bureau and the systemic risk committee will cover non-banks as well as banks. The creation of a consumer protection bureau is welcomed or hated, depending on one's philosophy, but it is the expanded rule making jurisdiction over non-banks and the added resolution capacity provided the government if financial institutions fail that is the most profound augmentation of federal authority in the Dodd-Frank legislation.

Regulatory changes, assuming they occur, will principally be of a judgmental rather than organizational nature. Rule making instead of definitive law will define the breadth and scope of what could become a more comprehensive regulatory regime.

The assumption is that stronger capital adequacy will be required in large financial institutions and that swaps clearing capacities will be strengthened. But banks, while encouraged, are not mandated to clear all transactions through exchanges or clearinghouses. And, ironically, insiders and their interest group allies were able in an inexplicable power play to remove, with one "grandfathered" exception, the most progressive provision in the CFMA of 2000, the authority of banking regulators to charter and oversee clearing facilities. If the single, fledgling Federal Reserve supervised special purpose clearing bank "grandfathered" under this Dodd-Frank provision chooses to change charters or is bought out by a CFTC supervised entity, the Federal Reserve will lose its direct capacity to oversee a key part of the derivatives market.

A citizen might ask what difference a regulator makes. In the case of derivatives clearing, it is profound. Integral to the development of rules for the financial industry is the knowledge a regulatory body must have of individual financial institutions and their potential counterparties. Key as well is an understanding of the incentives and disincentives that may 
exist for parties to use clearing facilities, and the authority or influence a regulator may have to advance policy in the public interest. A decade ago when markets seemed tamable, mega financial institutions fought coming under Federal Reserve jurisdiction of all kinds, especially derivatives clearing. Today in the wake of the financial disaster of the new century, they recognize their dependence on the Federal Reserve and Treasury

In this context, the case for the Federal Reserve to oversee derivatives clearing facilities for large banks is compelling. Only the Treasury is a credible alternative. How realistically can a non-bank regulatory body understand the standards individual banks should be required to meet and maintain to clear within a bank-centric clearinghouse? And as prescient as a nonbank regulator might be at a point in time, how could such a regulator have near the influence over banks that a bank regulator maintains because of the host of rules and regulations it must on a daily basis enforce?

As consequentially, what other governmental entity has the authority of either the Federal Reserve or the Treasury in international negotiations related to the development and maintenance of comparable standards for clearinghouses abroad so that financial institutions will not be incentivized to gravitate to clearing bodies outside the U.S. if they have less intrusive rules?

In the development of finance related statutes, I understood as a legislator that wordsmithing nuances could affect not only the national interest but various private sector competitive relationships, which is one of the reasons lobbyists galvanize like locusts on Capitol Hill. Competitive differences could at times be galling, but a company's or industry's concern for the bottom line was rationally explicable. By contrast, what frequently amazed me was the seemingly irrational intensity of competitive power considerations that would surface within the government. In turf battles for authority and hence jobs, rival regulators often had differences, sometimes vibrant hostility toward each other. Like the profit motive that governs private sector concerns, power considerations, sometimes microinstitutional, sometimes macropolitical, appeared too often to dominate regulatory judgments.

In the case of oversight of derivatives clearing, the revoking of critical authority from the two principal banking regulators represents a bureaucratic win for the CFTC and an interest group victory for the trading groups it oversees. But, despite a backup role potentially reserved for the Federal Reserve, this approach is at odds with the general direction of the Dodd-Frank bill which, above anything else, is intended to be an effort to strengthen the spine and broaden the jurisdiction of financial regulators.

While approaches to reform differed between the political parties in 2010, the one consensus goal of legislators was to avoid the prospect of further AIG-like bailouts. The common hope was that regulators would be in a position to rely on normal bankruptcy processes or the resources that banks provide the FDIC for resolution of failing institutions. The problem is 
that the FDIC fund that had been built up over decades has largely been exhausted. Accordingly, the Dodd-Frank bill confers on the FDIC authority to borrow from the Treasury up to an amount equal to the assets of any firm being liquidated.

Critics of the Dodd-Frank approach hold that governmental intervention provides less incentive for natural bankruptcy proceedings to unfold and thus increases the possibility that, in the name of stability, new burdens could be placed on taxpayers. Supporters, on the other hand, point out that this borrowing right is designed to give regulators discretion to develop techniques to help stabilize the impact a failing institution might have on the economy without imposing sudden new liabilities on the financial industry.

If the economy resumes solid growth, there is a credible prospect that over time the private sector can refurbish relevant insurance funds and that the risk of tapping the public can be reduced. But if new economic traumas are imminent, the prudential case for greater governmental discretion would appear compelling. It is to address the risk of future challenges as well as new dimensions to old problems that Dodd-Frank is in no small measure targeted.

What is clear today in finance is that regulators must use sophisticated techniques to understand modern markets and at the same time apply old-fashioned regulatory discipline to oversee a technologically changing financial system. In the last decade, however, the assumption was that modern financial engineering had so outstripped public sector ability to understand markets that regulators had no choice except to defer to private sector judgments. This meant deferring to the notion that risk-based financial modeling could be so prescient that the dangers of leveraging could be mastered. This in turn meant that management of financial institutions could increase per share earnings based on asset growth that lacked attendant capital cushions.

In addition to a more sophisticated understanding of modern markets, regulators and the institutions they oversee must have a more realistic understanding of the ramifications for finance of changes in geopolitics. For decades, concerns for such concepts as interest rate risk, credit risk, and country risk have dominated risk management committees within government and financial institutions. Now we are in a world where terrorism has for the first time been globalized, where experience is showing that protective steps can be taken but perfect insulation is impossible. Given the proliferation of weapons of mass destruction at one extreme and the potential damage that an angry few can inflict from any corner of the world with TNT and chemical compounds at the other, the premium risk factor that all in finance have to be concerned with for the foreseeable future is political risk of a very different dimension than was applied in a pre-9/11 framework.

There are few places in America where the consequences of 9/11 were discussed more than in the board rooms of financial institutions and their regulators. But, ironically, of the many 
aspects of the terrorist attack on New York and Washington, D.C., the one systemic response to protecting the financial system that was either not considered, or not insisted upon, may have been the most important: the necessity of developing greater capital cushions in the banking system.

It might be unfair to suggest that a governmentally sanctioned lowering of the guard occurred. Terrorism, after all, did not precipitate the financial crisis of 2008. But six years earlier, 19 terrorists struck at the heart of our financial and political capitals. It is historically premature to assess whether our interventionist response to those who transformed commercial planes into suicide bombs has made us politically secure. But the decision to defer the multitrillion dollar costs of two wars to subsequent generations and to compound these obligations with wartime tax cuts has clearly left us more vulnerable to a financial trauma. The surprise of 2008 was not that another blow was struck against the American way of life, but that it was self-inflicted. We were not prepared.

Regulators have often been considered financial police. Today the more appropriate analogy, at least for our largest banks, is to an international highway patrol. Driving in a fast lane can jeopardize the national defense. We cannot afford to have anything except strong banks. They are critical to economic security and job creation. Accordingly, when financial risk tests are considered, there is little alternative except to begin with concern for the implications of a multiplicity of easily imaginable, terrorist generated events as well as inflation/deflation challenges and the interconnectivity of international markets. In this setting, fragile capital cushions are inadequate security.

National security aside, two profound problems have unfolded with deferential regulation of the financial industry, one increasingly apparent, and the other less so. The increasingly apparent one is that when the invisible government accommodates highly leveraged approaches aimed at achieving greater per share near-term earnings for a few, the risks of higher social losses at a later point for the public increase, especially when systemic problems surface. The less recognized one is that finance has capricious as well as rationally foreseeable dimensions.

Even in systemically stable times, some seemingly well-run institutions are likely to falter when similar institutions may be quite profitable. The dichotomies of success or lack thereof are vastly complicated by the circumstance that banking institutions compete increasingly against a variety of non-bank financial firms, a number of which may be quicker witted with faster capacities to move capital than traditional banks.

While risk-reducing instruments have been developed to protect individual market participants, the sum total of their usage can at times increase systemic risk and, at all times, be misunderstood or misused by some financial parties. Hence, another irony of finance is that those who develop and market risk-reducing tools are unlikely to be able to protect 
themselves fully from all significant risks. The failure prospect of high end financial institutions may thus be greater than in years past.

Analogously, in an economy hallmarked by change and its acceleration, banks, particularly community institutions, are having difficulty finding enterprises to extend loans that are good credit risks. The Austrian economist Joseph Schumpeter's notion of creative destruction in capitalism may be jobs-neutral or better, but the faster the destruction rate, the greater the liabilities for financial intermediaries. Losses associated with unrecoverable loans to failing companies can quickly exceed profits based on loan spreads to companies that succeed. Traditional banking as well as other sectors of modern finance has thus become an increasingly risk-intensive enterprise.

There is always a tendency for reform legislation that passes Congress in the wake of a crisis to overreach. Critics believe that, like Sarbanes-Oxley, this may be the case with DoddFrank which, given the extent of public anger, awkwardly clips bank pricing discretion, perhaps moving banking closer toward a public utility model of regulation. Nevertheless, supporters convincingly point out that the bill adds important safeguards to the financial system. Support is provided for greater oversight of systemically consequential non-banks; greater resource options are given regulators to deal with failing institutions; advocacy is stated for higher capital standards; and, if regulatory cooperation can be obtained, increased use of clearing facilities is incentivized.

While the legislation is characterized by stated intent rather than legislative mandate, this intent is important. But it is not new. The discretion of bank regulators to insist on honest numbers and prudential leverage ratios has been fully authorized for more than half a century and methodologies for regulating derivatives have been available to the Executive branch and comprehensively advanced without consensus on Capitol Hill since the mid 1990s. Now under Dodd-Frank, prudential approaches will again be pointed to, but at a time governmental resources are dangerously stretched and economic stability sorely threatened.

Over the last two administrations, the size of derivatives markets mushroomed and the degree of recklessness in developing and marketing mortgage portfolios grew. Washington responded with a deregulatory bent. Regulatory bodies chose to accede to the leveraging instincts of large financial institutions in deference, if not awe, of Wall Street. In part, the loosening of regulatory standards was a reflection of an insider political/money game; in part, it related to an ideological reluctance to constrain markets; and in part, it was an offshoot of a manpower circumstance where markets and those participating in them increased in size and sophistication while Washington couldn't keep up.

While the economy and the financial security of the country were unnecessarily jeopardized by the unchecked greed of a few, statutorily directed deregulation did not occur. Regulation is fundamentally about the right and power of government to oversee markets. This right and 
power never diminished. Multipurpose institutions were authorized in 1999 but few came into being and the parts of each that did were subject to functional regulation that had been in place for half a century. Standards reduction was invisibly authorized.

Where Congressional accountability stands out is in the establishment of a problem-inducing GSE regulatory framework, in the exemption of credit default swaps from individual contract review, and in unsustained oversight of derivatives markets. The principal mistake of Capitol Hill was not what it did. It was what it failed on a timely basis also to do.

To a different degree, the same "not do/did do" perspective could be applied to the DoddFrank law. What it did not do was deal with housing finance where the woefully inadequate regulatory framework for GSEs helped precipitate the 2008 trauma. What the overhaul act did do was adopt the general framework of approaches to derivatives oversight that was laid out in comprehensive proposals and bills introduced in the 1990s on the House side of Capitol Hill but opposed by the two prior administrations and the majority of relevant committee members on both sides of the aisle in prior Congresses.

To recapitulate, the Dodd-Frank approach helps propel derivatives trading onto exchanges and into clearinghouses; gives regulators greater capacities to oversee mega non-banks; provides greater discretion in dismantling failing firms; and empowers a council of regulators to coordinate governmental policies. These approaches were all legislatively pressed a decade or more ago and in some aspects, such as clearinghouses, had been fully authorized by the end of the Clinton administration. As for dismantlement provisions, the key exemption of derivatives products from bankruptcy turmoil was legislatively authorized three years before the financial debacle occurred. And, while never precisely legislated, a council of regulators was utilized on an informal discretionary basis during several administrations, but it had never been as fully empowered as legislation of the 1990s envisioned and Dodd-Frank provides.

What this perspective suggests is that Congress was a day late in reaching consensus on aspects of regulation but the Executive branch and Federal Reserve were more than a dollar short in failing to exercise prudential authorities that they had accumulated over the last half century. Dodd-Frank fills in certain regulatory gaps and could help deter financial contagion in the future. But it is a mistake to assume that regulators and law enforcement did not have the legislated power before the financial calamity to enforce rules that would have substantially reduced the magnitude of the crisis that precipitated new legislation.

This perspective is crucial for the legion of new rule writers within the invisible government to think through. It implies that if calamity could have been significantly limited by applying more prudential judgment under the prior regulatory regime, the principal need today is less for social engineering than for the application of renewed attention to the regulatory basics. 
The emphasis should be on derivatives clearing, counterparty and terrorist risk, due diligence in marketing asset portfolios, and most importantly, on strong capital.

Financial industry stability is part and parcel of overall systemic stability. The public interest can be expected to be at variance with industry perspectives, but it is not identical with punitive rule making that could shutter the extension of credit. The meaning and affects of the Dodd-Frank legislation will not be known until the required 243 rule makings and 67 studies are completed. Too little balance in rule making or too much uncertainty in process could prove counterproductive for the economy. In particular, care must be taken to insure that so many studies and so much rule writing not cause the eye of regulators to be taken off the fundamental issue, capital adequacy. Invested capital and retained earnings remain the principal buffer between institutional misjudgment, systemic wrenches, and the public treasury.

The capital problem is highlighted if sophisticated derivatives strategies are used to leverage rather than protect capital. The temptation of the weak is to bet the house, knowing the speculator wins with a lucky hand but the taxpayer loses if there is an unfortunate turn of events. Without adequate skin in the game, derivatives market players could become like owners of weakly capitalized S\&Ls a generation ago who speculated with taxpayer insured funds. There are times in history that capital is king. In the wake of war and a stuttering economy, this is such a time in finance.

In the months since the financial trauma was sparked in 2008, regulators have understandably given attention in the U.S. and abroad to stress testing banks for similar events. While events of this nature can be simulated, their depth and consequences are difficult to predict with confidence. Predictions are unreliable because confidence factors are difficult to measure and the prospect of follow-on traumas difficult to gauge. Just as with nature where hundred year floods now seem to occur every decade, and where hurricanes seem to have higher force levels and frequency, manmade financial ruptures may be abbreviated from a once in a generation circumstance that used to confront Wall Street to more rapid fire challenges.

For more than half a century, regulators have had full authority to set prudential capital standards. From the perspective of community banks, our largest financial institutions have been granted unpardonable forbearance. In addition to off-balance sheet accounting gimmickry, they have been allowed to count long-term debt as part of Tier 1 capital. This definitional approach defies Webster's. Instead of debt being considered a liability and expense for a bank, it is arbitrarily designated a leverageable asset, making mockery of reported leverage ratios. A step forward would be to insist that bank borrowings be convertible to stock at bank or regulator discretion. Still, unless and until conversion, the question remains whether prudence should allow debt to be considered capital, at least for Tier 1 purposes. 
In the final measure, regulation as well as public confidence is based on the integrity of numbers and the manner capital is deployed. The financial crisis that America sprung on the world was in no small measure about too little capital in one place and too much in another. Too little capital with too much leverage was infused in large financial institutions. At the same time, too much capital with even greater leverage was employed in the American political system. The dual imbalance jeopardized the national interest. Hence, the cases for stronger capital standards in finance and progressive reform in campaign spending are entwined and compelling.

The principal oversight that now matters is of the public over its government. 


\section{References}

Greenspan, Alan. "Testimony by Alan Greenspan, Chairman, Board of Governors of the Federal Reserve System, before the Committee on Banking and Financial Services, U.S. House of Representatives, July 24, 1998."

http://financialservices.house.gov/banking/72498fed.shtml.

Hale, Thomas, Ed. 2008. Regional and National Financial Crises: Roots, Results and Responses," Policy Research Institute, The Woodrow Wilson School at Princeton University. November 7.

Leach, James A. 1994. "Derivative Regulations.” Congressional Record 140(2) (January 26). http://www.gpo.gov/fdsys/pkg/CREC-1994-01-26/html/CREC-1994-01-26-pt1PgH54.htm.

Leach, James A. 1995. H.R. 20 Risk Management Improvement and Derivatives Oversight Act, U.S. House of Representatives. http://frwebgate.access.gpo.gov/cgibin/getdoc.cgi?dbname=104_cong_bills\&docid=f:h20ih.txt.pdf.

Leach, James A. 2009. Address at the Symposium on Shaping Global Financial Reform. Sponsored by the Bretton Woods Committee and the Boston University School of Law. Washington, D.C. April 22. http://www.brettonwoods.org/events/index.php/54/Shaping_Global_Financial_Reform.

Paulson, Henry M. Jr., Robert K. Steel and David G. Nason. 2008. Blueprint for a Modernized Financial Regulatory Structure. The Department of the Treasury. March. http://www.ustreas.gov/press/releases/reports/Blueprint.pdf.

United States. Congress. House. Committee on Banking, Finance, and Urban Affairs. 1994. Safety and soundness issues related to bank derivatives activities : hearing before the Committee on Banking, Finance, and Urban Affairs, House of Representatives, One Hundred Third Congress, first session. Washington : U.S. G.P.O. 